\title{
Web System Reactiva TEC
}

\section{Sistema web reactivo TEC}

\author{
MORALES-ZAMORA, Vianney $\dagger^{*}$, PAREDES-XOCHIHUA, Maria Petra and SANCHEZ-JUAREZ \\ Iván Rafael
}

Tecnológico Nacional de México campus San Martín Texmelucan, Camino a Barranca de Pesos S/N San Lucas Atoyatenco San Martín Texmelucan, Puebla. C.P. 74120

ID $1^{\text {st }}$ Author: Vianney, Morales-Zamora / ORC ID: 0000-0002-1181-825X, Researcher ID Thomson: S-6627-2018, CVU CONACYT ID: 308547

ID $1^{\text {st }}$ Co-author: Maria Petra, Paredes-Xochihua / ORC ID: 0000-0003-1753-2313, Researcher ID Thomson: S-69912018, CVU CONACYT ID: 298117

ID $2^{\text {nd }}$ Co-author: Ivan Rafael, Sánchez-Juárez / ORC ID: 0000-0001-8296-5532, CVU CONACYT ID: 493160

DOI: $10.35429 /$ JCSI.2021.20.7.1.4

Received July 30, 2021; Accepted November 30, 2021

\section{Abstract}

This article presents the development and application of a web system that allows the registration of data from small businesses, in order to publicize their products and services, as well as their opening hours, type of payment received, location, social networks and telephone. There are three types of users: the administrator, the business owner, and the customer. The SCRUM methodology is applied for its development. Only the Execution and Adaptation phases will be presented in this article. In addition, its improvements and application in businesses in the San Martín Texmelucan región are visualized, an MVC architecture (Model-View-Controller) and free development technologies were used.

\section{Resumen}

Este artículo presenta el desarrollo y la aplicación de un sistema web que permite el registro de datos de pequeños negocios, con el fin de dar a conocer sus productos y servicios, así como sus horarios de apertura, tipo de pago recibido, ubicación, redes sociales y teléfono. Hay tres tipos de usuarios: el administrador, el propietario del negocio y el cliente. Para su desarrollo se aplica la metodología SCRUM. En este artículo sólo se presentarán las fases de Ejecución y Adaptación. Además, se visualizan sus mejoras y aplicación en los negocios de la región de San Martín Texmelucan, se utilizó una arquitectura MVC (Modelo-Vista-Controlador) y tecnologías de desarrollo libre.

System, Web, Economic

Sistema, Web, Económico

Citation: MORALES-ZAMORA, Vianney, PAREDES-XOCHIHUA, Maria Petra and SANCHEZ-JUAREZ Iván Rafael. Web System Reactiva TEC. Journal of Computational Systems and ICTs. 2021. 7-20:1-4

\footnotetext{
*Correspondence to Author (e-mail: vianney.morales@smartin.tecnm.mx)

$\uparrow$ Researcher contributing as first author.
} 


\section{Introducción}

The COVID-19 pandemic caused many in the way we live in Mexico and in the world, affecting various sectors, but mainly the economic one, since most business or trade changes closed a request from the corresponding authorities, in order to avoid further contagion between people. (TecNM, 2020)

From this, the need arises to create a web system, in which businesses that offer a product or service can register their address, hours, social networks, means of contact, forms of payment, etc. Based on this, that anyone with internet access and a mobile device with a web browser can access the system and consult the businesses based on their needs.

\section{Methodology}

Scrum is structured to help teams adapt naturally to changing conditions and user requirements, with shifting priorities built into the process and short release cycles so your team can constantly learn and improve (SCRUM, sf).

The SCRUM methodology for software development (Web system) includes the phases: Planning (planning of activities to be developed in the realization of the system), Execution (development of planned activities) and Adaptation (System development). But in this article we will only talk about the last two.

\section{Execution Phase}

In this phase, the work team develops its activities, including the development of the database, of the hi-fi screens, presented in Sprints, which are shown to the client for their feedback. The database was developed in Mysql, the high-fidelity screens use the boostrap framework, the php language, javascript and the Ajax, Jquery and Json plugins.

\section{Adaptation Phase}

6 Sprints were developed, in the first sprint the platform design was presented. See figure 1 .

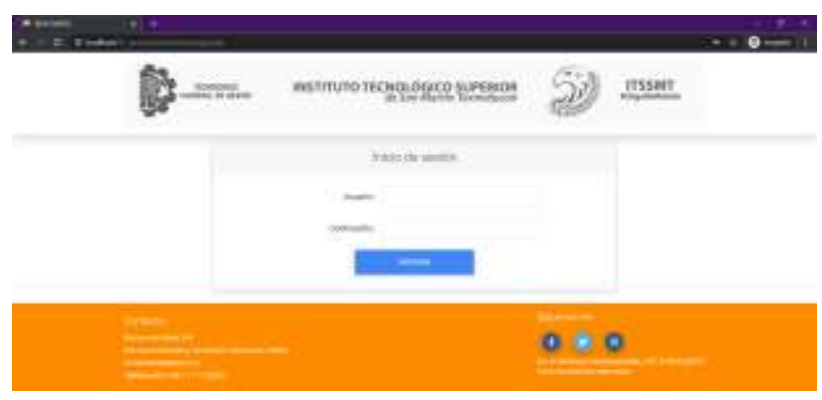

Figure 1 initial view

In the second sprint, the first hi-fi screens and the development of the database were presented (see figure 2).

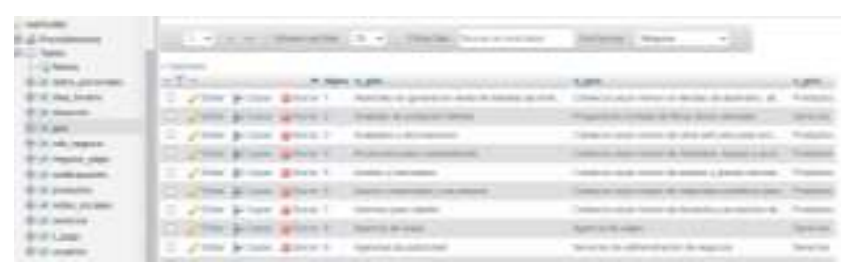

Figure 2 System database with its tables

In the third sprint it includes the connection with the database and user management. To prevent unauthorized users, without logging in or any other person from being able to access a module other than theirs (owners module or administrator module) via URL, the decision was made to establish a series of conditions when accessing the pages with those that the web system has.

\section{Said conditions are the following:}

If you try to access the owners or administrator module without first logging in, you will be automatically redirected to the home page where you must enter a username and password to access the respective module. If there is already an active session and an attempt is made to access a foreign module to which said user belongs or wants to return to the home page of the system, it will always return to the corresponding module of the user. (see figure 3 )

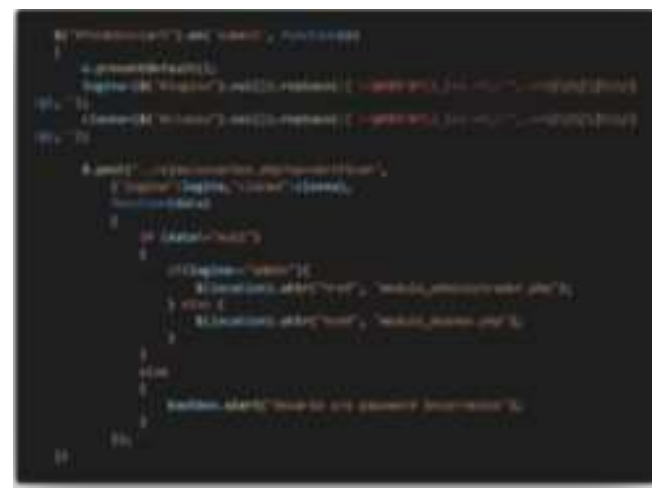

Figure 3 Session Identification

ESQUIVEL-SALAS, Abraham, CASTAÑEDA-DELGADO, Jaime, SALAS-GUZMÁN, Manuel Ignacio and ARREDONDO-SALCEDO, Daniel. Greenhouse temperature control based on Fuzzy Logic. Journal of Computational Systems and ICTs. 2021 
In the fourth sprint, the administrator user session is contemplated as shown in figure 4 , the values of the login form are obtained and through an Ajax request, it is checked if the user and password entered are correct. (see figure 5).

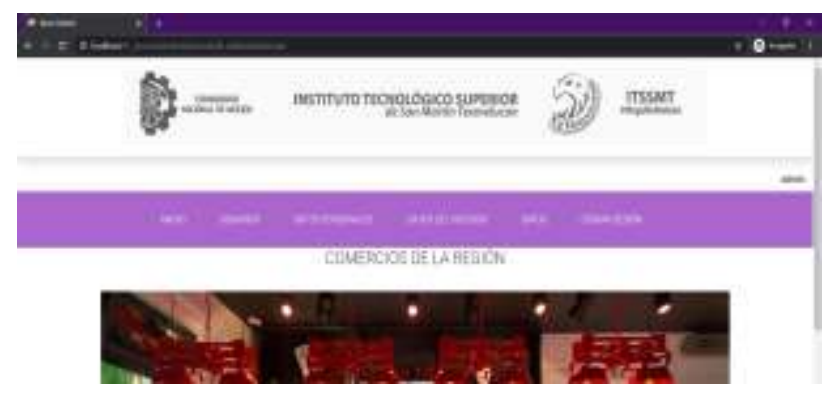

Figure 4 Administrator user session

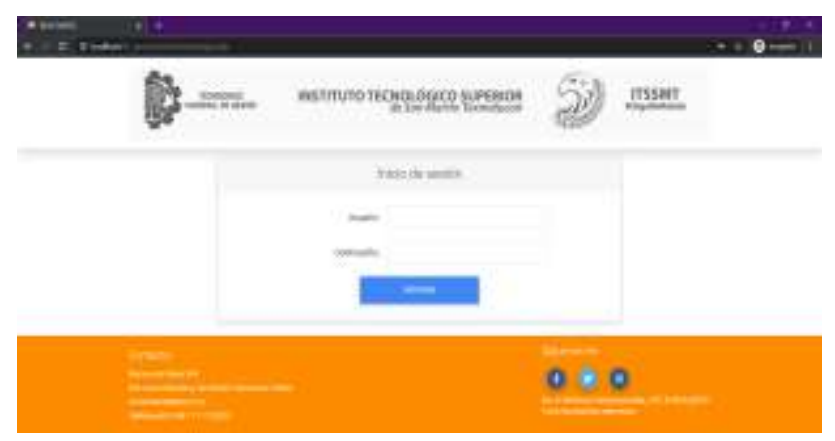

Figure 5 login

In the fifth sprint, the business owner user interfaces are shown.

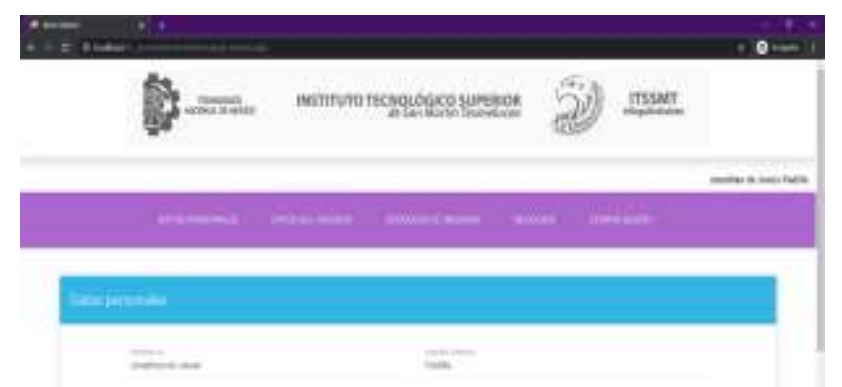

Figura 6 Business owner user session

And finally, in the sixth sprint, the feedback from the platform is presented. The SEPOMEX API was implemented, currently API COPOMEX, which is an independent project, which allows consulting the information of the postal codes of Mexico. (APICOPOMEX, 2021).

The information is obtained through an API, which returns the records in JSON format, in order to extract the settlement, neighborhood, municipality and state. (see figure 7)

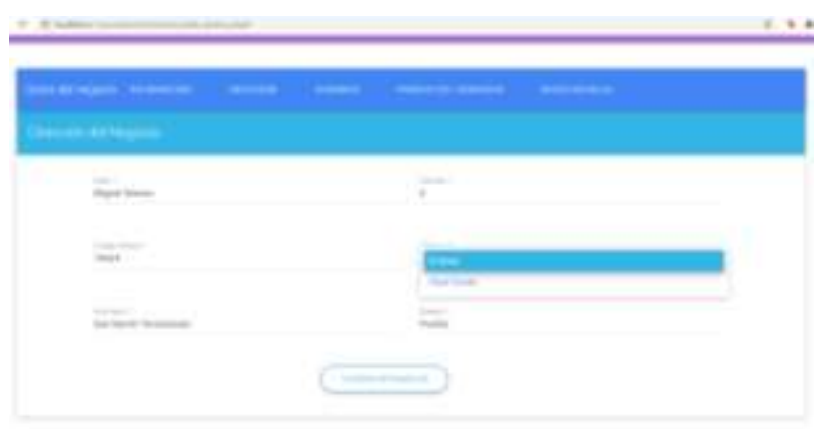

Figure 7 Form with postal code and settlements

Implement registration of more than one business per user. Initially, it was only planned that users (owners) could register a single business, but due to the analysis carried out in the institute, results were produced which showed that some of the people interested in the project had more than one business, which meant that a username and password had to be assigned for each of these. Figure 8 shows a list of the money orders to which the businesses registered in the system belong, whether they are products or services that they offer, the idg field -corresponds to the registration number, $\mathrm{n}$-giro is the name of the money order, d_giro - is the description of the turn, c_giro- is the type. However, the system is adapted to be able to register any type of micro-business, whether it offers products or services of any kind.

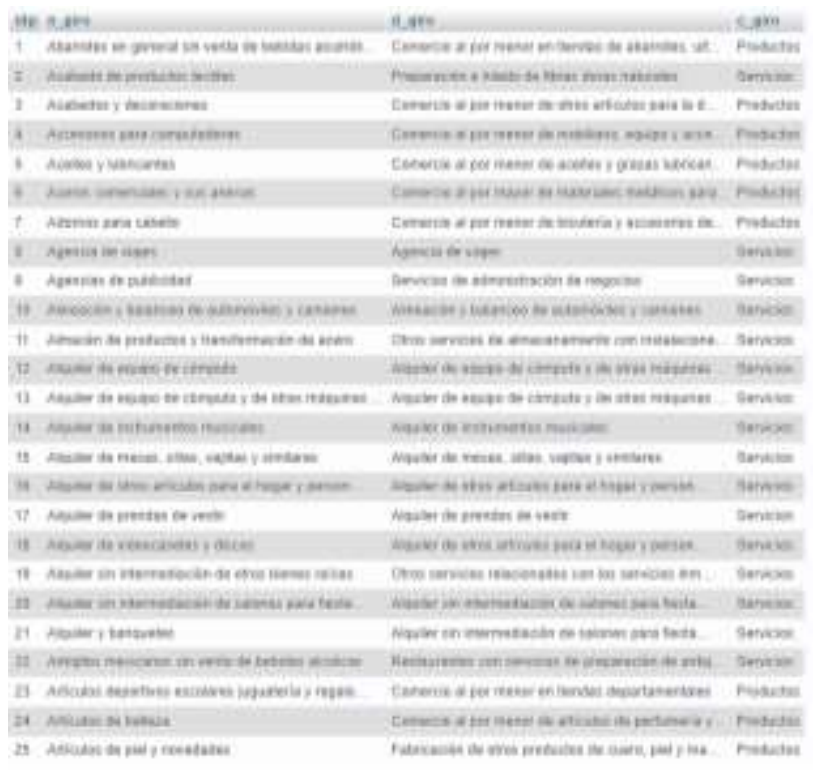

Figure 8 List of turns registered in the system

In this way, this functionality was implemented, so it was necessary to instantiate the Ajax request methods, since in the database models the function of adding a new business associating it to a user already existed. (See figure 9) 


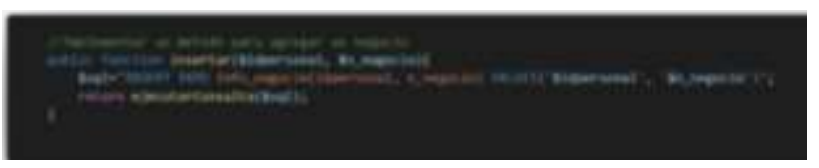

Figure 9 Insert business function

\section{Results}

With this project we work to promote the economic development of the San Martín Texmelucan region and with the support of students and teachers; so far, 400 businesses registered on the platform are supported. Stress and performance tests were carried out on the System with the JMeter software with the information presented in Table 1, where the requests simulate the number of users who enter the System, together with the time it takes to make the requests.

\begin{tabular}{|l|r|r|r|}
\hline \multicolumn{1}{|c}{$\begin{array}{c}\text { No. } \\
\text { Test }\end{array}$} & \multicolumn{1}{c}{$\begin{array}{c}\text { No. } \\
\text { Requests }\end{array}$} & \multicolumn{1}{c|}{$\begin{array}{c}\text { Time } \\
\text { (sec) }\end{array}$} & \multicolumn{1}{c|}{$\begin{array}{c}\text { Performance } \\
(\%)\end{array}$} \\
\hline 1 & 800 & 1 & 57.30 \\
\hline 2 & 800 & 3 & 40.90 \\
\hline 3 & 800 & 5 & 39.70 \\
\hline 4 & 900 & 1 & 49.60 \\
\hline 5 & 900 & 3 & 52.70 \\
\hline 6 & 900 & 5 & 45.30 \\
\hline 7 & 1000 & 1 & 78.40 \\
\hline 8 & 1000 & 3 & 67.40 \\
\hline 9 & 1000 & 5 & 87.70 \\
\hline
\end{tabular}

Table 1 Requests executed to obtain the \% performance

\section{Conclusions}

The System has been of great help to publicize small businesses in the San Martín Texmelucan region, and according to the survey conducted on October 12, 2021 to business owners, their sales have increased by 35 years. 50\%, after registering your business on the platform.

\section{References}

TecNM (2020). TecNM launches regional economic reactivation program. Recovered from:

https://www.tecnm.mx/?vista=noticia\&id=865

SCRUM (s.f.). What is SCRUM in Agiles Projects Agiles. Recovered from: https://proyectosagiles.org/que-es-scrum/

Boostrap (2021). Components. Recovered from: https://getbootstrap.com/docs/4.5/components/a lerts/
W3school (2021). CSS, html, javascript, php. Recovered from: https://www.w3schools.com/css/

API COPOMEX. (2021). COPOMEX. Recovered from: https://copomex.com/\#inicio 